\title{
Bringing Science and Technology Back to Congress
}

Congress is filled with members who have a broad range of expertise. Among the 535 members, there are scores of legal experts, business executives, educators, and community leaders. But there are only a handful of scientists. In fact, less than 5\% of current members have any scientific or technical training at all. More troubling still, Congress lacks a meaningful mechanism for receiving scientific and technological advice.

A brief review of the legislative agenda reveals that nearly every issue is in some way linked to science and technology. Just recently, Congress debated vital bills on stem cell research, energy policy, nanotechnology, and forest management. All of these topics require detailed scientific and technological analysis for accurate policy formulation. The September 11, 2001, terrorist attacks have put an even higher demand on lawmakers to grasp highly specialized scientific information. How can we responsibly address bioterrorism, airport security, and cybersecurity without the help of experts? Last year, the federal government spent billions of dollars on homeland security technology with limited understanding of the merits and effectiveness of the projects being funded.

Congress used to have scientific expertise at its disposal. The Office of Technology Assessment (OTA) was established in 1972 because lawmakers recognized a need for the legislative branch to have its own source of technical analysis. During its existence, the OTA provided Congress with unbiased technical analysis. In analyzing technological issues, the OTA adopted an interdisciplinary approach that resulted in reports that provided Congress with alternative views on a problem. To ensure a balanced approach, a Technology Assessment Board (TAB) - comprising six representatives and six senators, equally divided between Democrats and Republicans-governed the OTA.

At its peak, the OTA employed about 200 permanent staff members. Two-thirds of the staff consisted of professional research personnel with advanced degrees. Other research personnel were brought in temporarily to provide supplemental analysis for specific projects. To ensure a balanced approach, the OTA staff, outside experts, and the TAB reviewed all reports before they were released to the requesting committee. The OTA produced more than 750 reports in its 23 years of existence, and many of these reports are still relevant and in use. These reports cover a wide range of

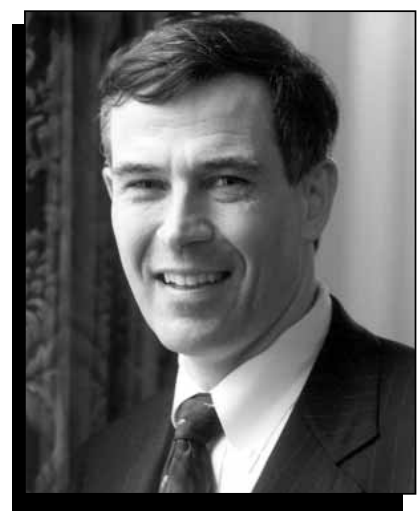

Rep. Rush D. Holt

topics, including missile defense, biological diversity, and alternative energies. The topics covered by OTA also include many related to materials science: advanced materials design, miniaturization technologies, microelectronics research and development, and commercialization of hightemperature superconductivity. All of the OTA's reports are available on the Web at URL www.wws.princeton.edu/ ota/.

The OTA became recognized worldwide. Representatives from about onethird of the world's nations visited the agency to learn how it worked and some subsequently used it as a model to provide technology advice to their own governments. Austria, Denmark, France, Germany, Great Britain, The Netherlands, and Sweden have all copied or adapted the OTA model.

In 1995, House Speaker Newt Gingrich and many others in Congress voted to dissolve the OTA with the stated intent of instituting government reform and cutting spending. On September 30, 1995, the OTA closed its doors, and Congress lost its only trusted, nonpartisan source of scientific and technical analysis. Congress has been without a dedicated source of scientific and technical analysis ever since.

Today, there is near-unanimous agreement in Congress of members' need for scientific advice. The question that remains, however, is how this capacity can be reconstituted in a way that meets the needs of legislators, falls within tight budget constraints, and garners broad political support. This question has been discussed in a variety of public fora and is the topic of a new book titled Science and Technology Advice for Congress, published in August by RFF Press. I believe that although improvements to the original OTA can be made, any entity capable of providing a similar capacity to Congress will retain many of the same features of the OTA, particularly those protecting the nonpartisanship of science-driven studies. That is why I have introduced a bill in each of the last three Congresses to reestablish the Office of Technology Assessment. Notably, support for this proposal is bipartisan. Original co-sponsors include the chair of the House Science Committee, Rep. Sherwood Boehlert (R-N.Y.), and Rep. Amo Houghton (R-N.Y.).

Another possibility is to house a technology assessment center in another existing agency, such as the Congressional Research Service or the General Accounting Office (GAO). Sen. Jeff Bingaman (D-N.M.) initiated a funding request two years ago to allow the GAO to perform a pilot technology assessment. The product of this effort, a report on biometrics for border security, was delivered to Congress late last year. External review of the assessment process and content of the GAO's report was largely favorable, and this study has already been cited in a Senate Judiciary Committee hearing on "Border Technology: Keeping Terrorists Out of the United States." Building on this success, the GAO will likely conduct two technology assessments this year, and the report language for the House-passed legislative branch appropriations bill instructs the GAO to conduct three technology assessments in fiscal year 2004. I strongly support building the technology assessment capabilities of the GAO, but believe that Congress must provide substantially more resources to allow the GAO to markedly scale up this effort and hire permanent technical personnel.

Fostering a better understanding of technological and scientific issues in Congress is necessary to produce enlightened, thoughtful public policy. The scientific community needs to continue advocating the restoration of a congressional capacity to assess and act upon scientific and technical information. Together, we can bring a better understanding of technological and scientific issues to Congress that will improve the legislative process.

ReP. Rush D. Holt

Rush D. Holt (D-N.J.) serves on the 21st Century Competitiveness and Select Education subcommittees of the House Committee on Education and the Workforce. He also serves on the House Permanent Select Committee on Intelligence. 